\title{
Securing Social Governability: Party-Movement Relationships in Lula's Brazil*
}

\author{
HERNÁN F. GÓMEZ BRUERA
}

Abstract. This article provides a new interpretation of the changes that occur in partycivil society relations when progressive parties of mass-based origin gain state power by looking at the experience of the Brazilian Workers' Party (PT) during the Lula administration. The need to preserve what is defined here as 'social governability' changes the nature of party-movement relationships when political parties move from opposition to government. The article shows how the PT in national executive public office, to a large extent, managed to secure social governability through reward-based linkages, such as the distribution of jobs in the state apparatus and the allocation of massive state subsidies.

Keywords: political parties, social movements, civil society, state-society relationships, Brazil, PT, Lula

\section{Introduction}

A number of scholars have argued that the Brazilian Workers' Party (Partido dos Trabalhadores, PT), a political organisation strongly linked to groups in civil society since its formation in I 979, has moved away from popular movements, grassroots organisations and trade unions, or even abandoned them as a result of its electorally maximising strategies and its presence in executive public office. ${ }^{\mathrm{I}}$ These views, which are nuanced in some cases and not

Hernán Gómez Bruera is a Postdoctoral Fellow, DPP, Centro de Investigación y Docencia Económicas (CIDE). hernanfgb@gmail.com

* This article is based on a doctoral research project on the trajectory of the Brazilian Workers' Party during the Lula administration. The author would like to thank Jonathan Fox, Kenneth Roberts, Peter Houtzager, Alex Shankland and other colleagues in the Institute of Development Studies (IDS), University of Sussex, for their valuable comments on this study.

' Margaret Keck, The Workers' Party and Democratization in Brazil (New Haven, CT: Yale University Press, I 992); Emir Sader and Ken Silverstein, Without Fear of Being Happy: Lula, the Workers' Party and Brazil (London: Verso, I 99 I); Gianpaolo Baiocchi, and Sofia Checa, 
necessarily unanimous, are nevertheless in line with prevalent ideas on partymovement relationships. ${ }^{2}$ Within the literature on political parties, authors consider that when political organisations adopt electoral strategies and increasingly hold public office, their relationships with social allies become weaker and more intermittent. ${ }^{3}$ A number of studies on social democratic parties in Europe show that when these parties entered public office they loosened their ties with their traditional allies, the trade unions. ${ }^{4}$ In a similar vein, the social movement literature suggests that political parties tend to move away from their allies in civil society when they enter government, and are able to maintain closer ties when they are in opposition than when they are in office. ${ }^{5}$

'The Brazilian Workers' Party: From Local Practices to National Power', Journal of Labor Society, I0:4 (2007), pp. 4 I I-30; Samuel Handlin and Ruth Collier, 'The Diversity of Left Party Linkages and Competitive Advantages', in Steven Levitsky and Kenneth M. Roberts (eds.), The Resurgence of the Latin American Left (Baltimore, MD: Johns Hopkins University Press, 20I I), pp. I39-6I; William Nylen, 'The Making of a Loyal Opposition: The Workers' Party (PT) and the Consolidation of Democracy in Brazil', in Peter Kingstone and Timothy Power (eds.), Democratic Brazil: Actors, Institutions, and Processes, (Pittsburgh, PA: University of Pittsburgh Press, 2000), pp. I26-43; Francisco de Oliveira, 'O Momento Lenin', Novos Estudos, 75: 4 (2006), pp. 23-47.

${ }^{2}$ Some scholars argue that the PT still maintains fluid relationships to civil society organizations: see Oswaldo Amaral, 'As transformações na organização do Partido dos Trabalhadores entre 1995 e 2009', unpubl. PhD diss., Universidade de Campinas. 2010; David Samuels and Thamy Pogrebinschi, 'Can Participation Shape National Politics? An Empirical Answer for a Theoretical Question', paper given at American Politicial Science Association, Annual Meeting, 20I2, available at http://papers.ssrn.com/sol $3 /$ papers.cfm? abstract_id=2 I0 $\mathrm{I}$ I I . Pedro Floriano Ribeiro, Dos sindicatos ao governo: a organização nacional do PT de Ig80 a 2005 (São Carlos, São Paulo, EdUFSCar/FAPESP, 2010) argues that the CUT and the PT, in particular, still have solid relationships.

${ }^{3}$ Richard Katz and Peter Mair, 'Changing Models of Party Organization and Party Democracy: The Emergence of the Cartel Party', Party Politics I: I (1995), pp. 5-28; Otto Kirchheimer, 'The Transformation of the West European Democracy', in Joseph LaPalombra and Myron Weiner (eds.), Political Parties and Political Development (Princeton, NJ: Princeton University Press, 1966), pp. 177-200.

${ }^{4}$ Elin Haugsgjerd, Political Parties and Interest Groups in Norway (Colchester, UK: ECPR Press, 2010); Adam Przeworski and John Sprague, Paper Stones: A History of Electoral Socialism (Chicago, IL: University of Chicago Press, 1986); Andrew Taylor, 'Trade Unions and the Politics of Social Democratic Renewal', West European Politics, I 5: I (1993), pp. 133-55. On the changing relationships between labour parties and trade unions in the context of a shift from a state-led to a market-oriented economy in Western Europe, see, among others, Frances Fox Piven, Labor Parties in Postindustrial Societies (Cambridge, UK: Polity Press, I99I); Javier Astudillo, 'Without Unions, but Socialist: The Spanish Socialist Party and its Divorce from its Union Confederation (1982-96)', Politics \& Society 29: 2 (2001), pp. 273-96.

5 Diarmuid Maguire, 'Opposition Movements and Opposition Parties: Equal Partners or Dependent Relations in the Struggle for Power and Reform?', in J. Craig Jenkins and Bert Klandermans (eds.), The Politics of Social Protest (London: UCL Press, 1995), pp. 99-I I2; Mildred Schwartz, 'Linkage Process in Party Networks', in Andrea Romele, Piero Ignazi, and David M. Farrell (eds.), Political Parties and Political Systems: The Concept of Linkage Revisited (Westport, CT: Praeger, 2005), pp. 37-56; Andrew Taylor, 
This article provides a different interpretation of the changes that occur in party-civil society relations when progressive parties of mass-based origin gain state power, by looking at the experience of the PT during the Lula administration in Brazil between 2003 and 2010 . It draws on archival research, secondary sources and more than 140 semi-structured open-ended interviews with PT members, including former presidents of the party, members of the national, state and municipal directorates; leaders of the main factions; party intellectuals; former mayors; PT legislators at all three levels of the Brazilian federation; and national government officials including ministers, secretaries, under-secretaries and presidential advisors. A number of leaders of some of the largest civil society organisations historically linked to the PT were also interviewed. On this basis, it is argued that what mainly changed in the PT case during these years, in contrast to both the current wisdom on party-movement relationships and the bulk of scholarship on the PT, was not the distance between the party and civil society organisations, but the way in which the PT engaged with these organisations due to the involvement of both the PT and many of its social allies with state institutions. Rather than a movement away, it is the nature of the relationship which mainly changes when a party shifts from opposition to government.

The nature of party-movement relationships changes not only because parties in public office are in a position to deliver, but also because they need to preserve governability, understood here as the need to balance conflicting interests in order to avoid the paralysis that can result from political, economic or social instability. As a multidimensional term, authors have generally distinguished political, economic and social dimensions of governability. ${ }^{6}$ This article is concerned only with social governability: the process by which a party in government seeks to reduce social and political contestation, keep conflict with civil society organisations (both allies and adversaries) at low or manageable levels; appease sources of opposition against its main policies, avoid social unrest and promote a minimum sense of stability and public order within society at large.

'Trade Unions and the Politics of Social Democratic Renewal', West European Politics, I 5: I (1993), pp. 133-55.

${ }^{6}$ See, among others, Fernando Mayorga and Eduardo Córdova, 'Gobernabilidad y Gobernanza en América Latina', Geneva, Institut Universitaire d'Etudes du Développement, Working Paper Norte-Sur IP8, 2007; Joan Prats, 'Gobernabilidad democrática para el desarrollo humano: marco conceptual y analítico', Revista Instituciones y Desarrollo io (200 I), pp. 103-48; Luciano Tomassini, 'Estado y gobernabilidad', in 'La reforma del estado y las políticas públicas', Working Paper, Santiago, Centro de Análisis de Políticas Públicas, 1993. I have examined elsewhere the economic and political dimensions of governability during the Lula administration: see Hernán Gómez, Lula, the PT and the Governability Dilemma in Brazil (New York: Routledge, 2013). 
The article shows how, to a large extent, the PT in national executive public office managed to secure the social dimension of governability through rewardbased linkages, such as the distribution of jobs in the state apparatus and the allocation of massive state subsidies. The Lula administration, not always as a result of a consciously calculated strategy, used these elements to keep disruptive practices at low or manageable levels and secure support from an important sector of civil society. It was mainly as a result of these practices, some of which started when the PT occupied national executive public office, that the relationships between the party and its social allies were transformed.

Drawing on the literature on party linkages, it is argued here that rewardbased linkages, in which parties in government exchange specific favours with groups in civil society in order to obtain political support, acquired greater salience when the PT occupied national executive public office. 7 Therefore, a relationship which was originally based on the promotion of universal and general aims and encouraged collective rather than particularistic solutions moved towards the provision of benefits to specific groups or individuals who engaged in a contract-like exchange relationship. Through this process, the PT managed to maintain close and long-lasting relations with its social allies.

When looking at the relationship between the Lula administration and civil society organisations, the article concentrates mainly on one side of this relationship - the party in public office - and less on the party as a bureaucratic organisation.$^{8}$ The attempt is not to elaborate on the behaviour of the rather diverse social groups in the PT entourage, but to analyse common tendencies in the type of linkages that the party in the national executive established with some of the most influential organisations in the PT camp. Rather than looking at identity groups, this article focuses on the patterns to be found in the PT's relationship with class-based organisations which are particularly relevant for socio-economic redistribution. Specifically, this means examining its links with the Central Workers' Union (Central Única dos Trabalhadores,

7 For this literature, see, among others, Kay Lawson, Political Parties and Linkage (New Haven, CT: Yale University Press, I 980); Kay Lawson and Peter Merkl, When Parties Fail: Emerging Alternative Organizations (Princeton, NJ: Princeton University Press, 1988); Haugsgjerd, Political Parties and Interest Groups in Norway; Herbert Kitschelt, 'Linkages between Citizens and Politicians in Democratic Politics', Comparative Political Studies, 33: 3 (2000), pp. 845-78; Piero Ignazi, David Farrell and Andrea Romele, 'The Prevalence of Linkage by Reward in Contemporary Parties', in Romele, Ignazi and Farrell (eds.) Political Parties and Political Systems, pp. 17-35.

${ }^{8}$ On PT organization, see, among others, Pedro José Ribeiro, 'Dos sindicatos ao governo: a organização nacional do PT de 1980 a 2005', unpubl. PhD diss, Universidade Federal de São Carlos, 2008; Amaral, 'As transformações na organização do Partido dos Trabalhadores'; Wendy Hunter, 'The Normalization of an Anomaly: The Workers' Party in Brazil', World Politics, 59: 3 (2007), pp. 440-75; David Samuels, 'From Socialism to Social Democracy: Party Organization and Transformation of the Workers' Party in Brazil', Comparative Political Studies, 37: 9 (2004), pp. 999-1024. 
CUT); the Landless Workers' Movement (Movimento dos Trabalhadores Rurais sem Terra, MST); the National Confederation of Rural Workers (Confederação Nacional dos Trabalhadores na Agricultura, CONTAG); and the Housing Movement, which constitute historical PT allies and some of the most significant social organisations in contemporary Brazil. Given the diversity of Brazilian civil society, the findings do not necessarily apply to all organisations in the same way. Rather, the study seeks to contribute to a broader and more ambitious research agenda on the relationship that progressive parties in government establish towards their allies in civil society.

In order to capture the complex and changing nature of relations between the PT and its traditional allies, it is useful to introduce the notion of the party socio-political field (or party field). 9 This term allows us to look beyond the formal boundaries of party and civil society organisations, which are very often blurred, as Goldstone has noted in his influential work on party-movement relationships. ${ }^{\circ}$ The party field is a network of social and political actors that act beyond their formal organisations, independent from their membership of the party or of a specific group in civil society. Such actors often wear 'double hats' or they move back and forth between civil and political society, while their activities are not restricted to their formal organisations. The notion of a party field captures a whole web of informal relations between the party and leaders in civil society which take place beyond institutional mechanisms. It covers a large network of cadres, leaders and social activists who are strongly identified with the party, even if they lack any formal affiliation.

The article is divided in four sections. The first explores in a succinct way the type of relationship established between the PT and its allies in civil society when the PT was in opposition, and later on, when it occupied subnational and national executive public office. The second elaborates on the notion of social governability and its implications. The final two sections study the development of reward-based linkages, first by focusing on the use of patronage practices and how this became an instrument to secure social governability at the national level, and then by considering the role of state subsidies, which had similar effects.

9 This term has no direct relationship with the broader concepts of political and social fields used by Pierre Bourdieu.

${ }^{10}$ Jack Goldstone, 'Bridging the Gap between Institutionalized and Non-Institutionalized Politics', in Jack Goldstone (ed.), States, Parties and Social Movements, (Cambridge: Cambridge University Press, 2003), pp. I-24; see also Michael Hanagan, 'Social Movements: Incorporation, Disengagement and Opportunities - A Long View', in Marco G. Giugni, Doug McAdam and Charles Tilly (eds.), From Contention to Democracy (Oxford: Rowman \& Littlefield, 1998), pp. 3-30. 


\section{The PT and its Allies in Civil Society}

From the time that the PT was formed, a strong link to civil society organisations became a symbol of the party identity and a defining feature of the party ideology. Unlike other labour-based parties, the PT was not only an important ally of the urban labour movement. It also forged important links with rural trade unions, landless workers around the country and the progressive sector of the Catholic Church. ${ }^{I}$ From the outset, the party incorporated the demands of specific social sectors in its programmes, creating strong linkages that were based on complementary goals and agendas addressed at promoting socio-economic redistribution. ${ }^{22}$

From the late 1980 os and throughout the 1990 , the PT and many of its social allies experienced a reconfiguration of their goals and strategies, which affected the way in which they related to each other and approached the state. Because political institutions became more inclusive in the post-democratic transition years, the state turned into a critical platform from which both social and political leaders in the PT entourage sought to promote their views and interests. On the one hand, the dominant coalition in the party became more pragmatic. It incorporated strategies of incremental social change and adopted a coherent electoral route to power, which resulted in the endorsement of the rules and dynamics of formal representative democracy. On the other hand, several civil society organisations, such as the CUT or the Housing Movement (although not others such as the MST) adopted more moderate practices, increasingly engaged in processes of negotiations with the state and deploying strategies that were less confrontational and disruptive.

Pedro Ribeiro, who has written extensively on the transformations of the PT, argues that because the party became a large and competitive political machine, but mainly because it approached the state and became dependent on its material and financial resources, its relationships with civil society organisations (CSOs) experienced a 'relative quenching'. ${ }^{13}$ However, survey studies and my own empirical findings not only suggest that the PT still maintains close and fluid relationships with leaders and organisations, but also that it

I Sue Branford, 'Lidando com governos: o MST e as administrações de Cardoso e Lula', in Miguel Carter (ed.), Combatendo a desigualdade social: o MST e a reforma Agrária no Brasil (São Paulo: Editora da UNESP, 2010), pp. 409-32; Peter Houtzager, 'Social Movements amidst Democratic Transitions: Lessons from the Brazilian Countryside', Journal of Development Studies, 36: 5 (2000), pp. 59-88; 'Collective Action and Political Authority: Rural Workers, Church and State in Brazil', Theory and Society, 30: I (2001), pp. I-45.

${ }^{12}$ Lincoln Moraes, 'Crônica de um partido não anunciando: programa e governos do PT entre 1979-2000', unpubl. Master's diss., University of Campinas, 2004, pp. I 44-64.

13 Pedro Floriano Ribeiro, 'An Amphibian Party? Organisational Change and Adaptation in the Brazilian Workers' Party (1980-2012).' Journal of Latin American Studies, 46: I (2014), pp. 87-II9. 
is extremely influential in some of the most important groups in civil society, while party leaders in public office, both in the legislative and the executive branch, have frequent interaction with some of its most influential leaders.

First, there are elements suggesting that party delegates did not leave their organisations as a result of their growing immersion in public office, whether by being elected as officials or as bureaucratic appointees. Surveys conducted during party congresses and national meetings between 1997 and 2007 by the party's principal think-tank, the Fundação Perseu Abramo, show that almost two-thirds of the 'middle level elites' have maintained some kind of 'participation', in at least one CSO between 1997 and 2007. ${ }^{14}$ As Amaral suggests, middle level elites within the party have maintained a 'double activity' by which they simultaneously play a role in civil society and in public office. ${ }^{\text {is }}$ Despite the fact that party leaders became closer to state institutions, this did not result in them dissociating themselves from civil society.

Second, there is evidence that elected PT leaders have maintained constant interaction with groups in civil society. A survey study of the party's congressional representatives (called Deputados) shows that 62 per cent of them acknowledged that their election was largely made possible by their linkages with a specific social movement. ${ }^{16}$ The study also found that the average PT representative in Congress dedicates half of his or her time ( 52 per cent) to interacting with their electoral bases, which are mainly CSOs. ${ }^{17}$ PT congressional representatives interviewed for this study confirmed that they have an ongoing relationship with groups in civil society, receiving their leaders for all sorts of purposes on a continual basis, particularly within the Left and Centre-Left factions. ${ }^{18}$

Third, for some of the largest and most important CSOs in Brazil the PT is still the main reference within party politics. Sources within organisations like the CUT, CONTAG and the Housing Movement confirm that the PT is, by and large, their main entry point to the political system as well as the first party to which the majority of its members are affiliated or for which they vote. ${ }^{19}$ In

${ }^{14}$ Ibid, p. I 8. The term 'participation' was not defined in specific terms in the survey.

is Amaral, 'As transformações na organização do Partido dos Trabalhadores', p. 91.

${ }_{16}$ The survey was conducted among 47 PT congressional representatives elected for the 19992002 term (80 per cent of all PT representatives were interviewed), Paulo Roberto Figueira, $O$ $P T$ e o dilema da representação política: os deputados federais são representantesde quem? (São Paulo, FGV Editora, 2005), p. 83.

17 Ibid., p. I 14.

${ }^{18}$ Interviews with PT congressional representatives, Florisvaldo Fier, 3 Dec 2008; Iriny Lopes, 3 Dec 2008; Adão Pretto, 2 Dec. 2008 and Eduardo Suplicy 7 April 2008.

19 This diagnosis was made by a large number of civil society leaders or activists interviewed for this study; in the CUT: Celestino, 16 Dec. 2009; Artur Henrique, I 5 April 2009; and Antonio Lisboa 21 Oct. 2010; in CONTAG: Edson Campos 3 July 2009; Manoel dos Santos, 3 July 2009, and Beze Zeke, 3 July 2009; in the Housing Movement: Donicete Fernandes, 7 Jan. 2009; Luiz Gonzales, I I Nov. 2008; and Dorival Gomes, I 3 Nov. 2008. Within the PT this information was confirmed by Renato Simões, 4 Nov. 2008, PT 


\section{Hernán F. Gómez Bruera}

the case of the MST, an important, albeit undetermined, number of leaders officially left the party during the I990s and in the early months of the Lula administration, mainly as a result of the economic policy adopted by the new government. However, the PT is still influential at the grassroots level, as some of its leaders acknowledge. ${ }^{20}$ Interestingly, scholars have found that no other party in Brazil has substituted the PT in its capacity to liaise with civil society organisations. ${ }^{21}$

Last but not least, quantitative data show that the party has continued to recruit social activists. The great majority of the party delegates who joined the PT after its formative years were still overwhelmingly from civil society or, more precisely, claimed to participate in a specific organisation when they became affiliated to the party. In 2007, the Fundação Perseu Abramo asked delegates who became PT members at five different moments in the PT history whether they had participated in a CSO at the time they formally joined the party. As Amaral reported, the percentages were never below the initial threshold, remaining always above 80 per cent on all five occasions (1980-82, 81.4 per cent; I983-89, 84.3 per cent; I990-94, 87.0 per cent; I 995-99, 80.3 per cent; $200 \mathrm{I}-2007,82.9$ per cent). ${ }^{22}$ The numbers seem to confirm that the PT never ceased to incorporate cadres with a civil society background into its structure.

Unlike Ribeiro, who assumes that the PT took a certain distance from its allies in civil society when it increased its exposure to public office, it is suggested here that this is not necessarily the case, because both the party and its allies made a movement towards the state. What happened, however, was that when the PT started to occupy public office, first at the sub-national level, and then in the national sphere, party leaders and social activists became related in a different way, given that the party in government was in a position to deliver, not only public goods, but also particularistic benefits in the form of jobs and state subsidies to civil society organisations. The way in which the PT

Secretary for Popular Movements; José Dirceu 7 Jan. 2009, Lula's former Chief of Staff and PT president; and Valter Pomar, 30 Sep. 2008, leader of Left Articulation. Unfortunately, there are no statistical data on the number of PT members and sympathisers within specific organisations vis-à-vis other parties.

${ }^{20}$ Interviews with MST leaders Alexandre Rangel, 8 Apr. 2009; and Clarice dos Santos, 7 May 2009.

${ }^{21}$ Samuels has found, for instance, that PT members still differed from non-PT members in their level of social engagement: see David Samuels, 'Sources of Mass Partisanship in Brazil', Latin American Politics and Society, 48: 2 (2006), pp. I-27. Recent work by Samuels and Zucco explains how the PT's electoral strategy largely aims at mobilising the organised sectors: see David Samuels and Cesar Zucco, 'The Power of Partisanship in Brazil: Evidence from Survey Experiments', American Journal of Political Science, 58: I I (2014), pp. 212-25.

22 Amaral, 'As transformações na organização do Partido dos Trabalhadores', p. 95. 
embraced electoral politics after the mid-r 990 s and penetrated state institutions had significant consequences. The relationship between the PT and CSOs acquired a more instrumental character, as the linkages between the party in public office and CSOs became more reward-based and, for reasons that this article does not analyse in depth, less programmatic. ${ }^{23}$

The relationships between the party and its social allies changed in public office mainly because it was shaped by the logics of governability. In this regard, CSOs became a strategic actor, given their capacity to affect the delivery of essential public services or to generate social unrest. In São Paulo, for instance, the administration of Luiza Erundina ( $1989-92)$ confronted numerous strikes by, among others, the CUT-affiliated Bus Drivers' Union, which in May 1992 caused a total shutdown of the public transportation system for nine days. ${ }^{24}$ Likewise, in the southern state of Rio Grande do Sul, 90,000 members of the Teachers' Union (CPERS), one of the largest trade unions in the state, went on strike against the PT administration in 2000. Teachers demanded a I 90 per cent pay rise, whilst the government of Olívio Dutra, citing serious financial constraints, offered ro per cent. ${ }^{25}$ The strike extended to 32 days, severely affecting the administration, the public image of the PT in the state and the attempts of the party to elect another governor in 2002 .

Eventually, the distribution of jobs to specific leaders helped a number of PT mayors to accommodate the interests of civil society organisations in order to contain disruptive practices or keep them at low or manageable levels, hence securing social governability. During the mayoral administration of Marta Suplicy in São Paulo (2000-04), numerous leaders from the Housing Movement were appointed to office. ${ }^{26}$ It is suggested that, as a result, 'the government and the social movement almost came to a truce' during this period, while the Housing Movement stopped demonstrating outside the Secretariat of Housing as they so frequently had done during previous administrations headed by conservative parties. ${ }^{27}$ The fact that this movement supported

${ }^{23}$ For an account of the effects of the consequences of embracing electoral politics on the programmatic linkages between the PT and its social allies during the I990s, see Gómez, Lula, the PT and the Governability Dilemma in Brazil, pp. 47-50.

${ }^{24}$ Fiona Macaulay, "“Governing for Everyone”: The Workers' Party Administration in São Paulo, 1989-1992', Bulletin of Latin American Research, I 5: 2 (1996), p. 223.

${ }^{25}$ Benjamin Goldfrank, and Aaron Schneider, 'Restraining the Revolution or Deepening Democracy? The Workers' Party in Rio Grande do Sul', in Gianpaolo Baiocchi (ed.), Radicals in Power: The Workers ' Party and Experiments in Urban Democracy in Brazil (London: Zed Books, 2003), p. 162.

${ }^{26}$ Gustavo Carneiro, 'Uma concessão ao passado: trajetórias da união dos movimentos de moradia de São Paulo', unpublished Master's thesis, Departamento de Sociologia, Universidade de São Paulo, p. 93; Ana Cláudia Chaves Teixeira, Os sentidos da democracia $e$ da participação (São Paulo: Polis, 2005), p. 52; Narcisa Whitaker, 'Os sem-teto do centro de São Paulo: um balanço dos anos 200I-2004', unpubl. PhD diss., University of Campinas, 2008, p. I I.

${ }^{27}$ Carneiro, 'Uma concessão ao passado', p. 94. 
Suplicy's candidacy and several PT candidates running for legislative positions did not always involve a particular commitment of the party to the causes that such organisations promoted. Indeed, the housing sector was not even a priority of the Suplicy administration. ${ }^{28}$ Notwithstanding the fact that a number of leaders obtained jobs in government, this did not necessarily contribute to strengthening programmatic linkages. When studying the performance of the Housing Movement during the Suplicy administration, Gustavo Carneiro argues that the government used political appointments to exercise 'individual pressure' in order to discourage activists from becoming involved in collective actions that could 'destabilise the administration'. ${ }^{29}$

\section{The Ends and the Means of Social Governability}

The literature on party-movement relations shows how parties in government tend to prefer 'more standardized' and 'non-threatening forms of collective action', and are likely to seek to reduce the 'potential disruptive effects' of social movement activity. ${ }^{\circ}$ Some parties in public office might mobilise their own social bases to support specific policies, but will certainly discourage collective action against their own policies. The PT has been no different in this sense. During interviews with PT leaders, a city councillor with historical ties to social organisations put it bluntly: 'A government that is questioned every day becomes too unstable and compromises its own project', he said. 'No government can cope with a situation in which it is permanently attacked'. ${ }^{3}$ During the Lula administration this approach was also internalised by some of the PT allies in civil society. Two members of CONTAG, for instance, made the following point in an interview: 'When you are in opposition you are not responsible for governability. Your actions are done in order to erode the existing government. When the government that you helped to elect is in power you maintain pressure with responsibility'. ${ }^{32}$

Parties in public office are not likely to promote mobilisation processes that might escape their control. In the PT case, given the difficulties that democratically elected left-wing parties had faced in the past when dealing with their allies in civil society, the need to avoid a mobilisation process that could get out of control was a particularly relevant aspect. By and large, over-radicalised

${ }^{28}$ Ibid.

${ }^{29}$ Ibid, p. 93.

${ }^{30}$ Patricia Hipsher, 'Democratic Transitions as Protest Cycles: Social Movement Dynamics in Democratizing Latin America', in David S. Meyer and Sidney G. Tarrow (eds.), The Social Movement Society: Contentious Politics for a New Century (Oxford: Rowman \& Littlefield, 1998), p. 157; David S. Meyer The Politics of Protest: Social Movements in America (New York: Oxford University Press, 2007), p. I 26.

${ }^{31}$ Interview with Jorge Camilo, 16 Nov. 2010, PT city councillor.

${ }^{32}$ Interviews with Adriana Borba and Anice Cleia, 3 April 2008, members of CONTAG. 
or too undisciplined societal groups are never good allies. This concern was clearly seen in the PT national administration from the outset. Not coincidentally, what Lula mainly asked his supporters for in his inaugural speech on I January 2003 was 'patience', while he made an appeal to 'keep our many legitimate social concerns under control so that they can be addressed at the right pace and at the right moment'. ${ }^{33}$

Parties use a wide range of strategies to promote more routinised and predictable forms of mobilisation and to limit their potentially disruptive effects. Some governments simply repress mobilisation, while others try to integrate social organisations into established political channels, as shown by the experience of post-democratic Brazil referred to earlier. In the case of the Lula government, there is a consensus among scholars, PT members and leaders in civil society that, unlike Cardoso, Lula's government did not resort to repressive practices. ${ }^{34}$ Rather, the administration put in place an unprecedented 'opendoors' policy towards civil society organisations, allowing dialogue and negotiation to become common practice. In this regard, leaders noticed the difference between the Cardoso and Lula administrations. Arthur Henrique, elected as CUT leader in 2006, recalls that 'we were coming from the experience of a government that did not listen to us, did not receive us and called the police to solve trade union problems'. In his view, 'Lula changed all this radically', as many negotiation spaces were opened to them in matters such as the minimum wage, small-scale agriculture or education. ${ }^{35}$

Brazilian political scientists such as Wanderley Guilherme dos Santos and Leonardo Avritzer have emphasised that the Lula administration was the first since 1964 in which no-one lost their lives for mobilising against the federal government. ${ }^{36}$ Even in the case of the MST, one of the most radical organisations in the PT field, the fact that the organisation increased the number of occupations of land and public buildings from the first year of the Lula administration did not result in the violent clashes with national security forces that had been so common in previous years. ${ }^{37}$ This supports

${ }_{33}$ Folha de S. Paulo, 'Leia a integra do discurso de posse do presidente Lula', i January 2003.

${ }^{34}$ Interviews with Leonardo Avritzer, I 3 July 20 I o, scholar; and Miriam Belchior, 6 July 2009, presidential advisor; Kathryn Hochstetler, and Elisabeth Friedman, 'Can Civil Society Organizations Solve the Crisis of Partisan Representation in Latin America?', Latin American Politics and Society, 50: 2 (2008), pp. I-32; Sergio Sauer, 'Rural Social Movements and their Historical Contribution for Building Democracy in Brazil', Transnational Institute, 2008, available at www.tni.org/archives/rural/sauer_ruralmovementsbrazil.pdf.

35 Interview with Artur Henrique, Is April 2009, president of CUT.

${ }^{36}$ Interview with Leonardo Avritzer, I 3 June 20 I0; Wanderley Guilherme dos Santos, 'Lula e sua herança', Carta Capital, 20 January 20 I I.

37 Kathryn Hochstetler, 'Civil Society in Lula's Brazil', Centre for Brazilian Studies, University of Oxford, Working Paper CBS-57-04, 2004, p. I 3. It is worth noting, however, that incidents of rural violence involving assassinations, despite not involving national security forces, are still common in many Brazilian states. 


\section{Hernán F. Gómez Bruera}

the idea that the PT in national public office was able to manage social conflict successfully, not least by accommodating the interests of key strategic actors in civil society in a way that limited disruptive actions.

From the very start, Lula incorporated social organisations into various institutionalised and non-institutionalised mechanisms. These mechanisms included institutions of participatory governance such as sectoral policy councils and national conferences, created in Brazil in the post-democratic transition years. ${ }^{3}$ It also included a practice of negotiation with a wide array of social organisations which was a hallmark of the PT national administration. Many of these negotiations took place in formally established or newly created ad hoc institutional mechanisms, while many others happened spontaneously in private and non-institutional settings. The presidential palace of Planalto was symbolically opened to the visits of leaders of social movements and trade unions, who were not regular guests in the past and who came to meet senior officials (and sometimes the president himself) more frequently. In addition, as shown in the following sections, reward-based linkages mainly patronage strategies and state subsidies - facilitated compromise, and discouraged more radical or potentially disruptive forms of collective action.

\section{Patronage Strategies under Lula}

The distribution of jobs among several social activists and trade union leaders during the Lula government had several important implications. Not only did it become a form of inclusion, but it also helped to secure social governability. Once in national executive public office the PT put in place a recruitment practice similar to the one used by the party in many of its local administrations. ${ }^{9}$ There was a significant change of scale, however, given the fact that in Brazil the executive branch has discretionary power to recruit a large number of bureaucrats within government ministries, agencies and state foundations. ${ }^{40}$ According to Maria d'Araujo, in 2003 the Lula administration had

${ }^{38}$ See, among others, Gianpaolo Baiocchi and Sofia Checa, 'The Brazilian Workers' Party: From Local Practices to National Power', Journal of Labor Society, io: 4 (2007), pp. 4I I30; Cláudia Feres, 'Estado e organizações da sociedade civil no Brasil contemporâneo: construindo uma sinergia positive', Revista de Sociologia e Politica, i 8: 36 (20 10), pp. 187-204; Wendy Hunter, The Transformation of the Workers' Party in Brazil (1989-2009) (Cambridge: Cambridge University Press, 2010); Clovis Henrique Leite, 'Partilha de poder decisório em procesos participativos nacionais', unpublished Master's diss., Instituto de Ciência Política, University of Brasília, Brasília, 2008; Samuels and Pogrebinschi, 'Can Participation Shape National Politics?'.

39 Hochstetler, 'Civil Society in Lula's Brazil', p. I I.

40 Celina Souza, 'Os ministros da Nova República: notas para entender a democratização do poder executivo', paper presented at the II Congresso de Gestão Pública, Brasília, 6-7 May 2009, available at wwwi.seplag.rs.gov.br/upload/Painel_60_Maria_Celina_DArajo_ formatado.pdf. 
powers to freely appoint 17,559 cadres (a figure that had risen to 19,797 in 2006) from directorate level upwards. ${ }^{41}$ A significant portion of them, not necessarily the majority, were leaders of social organisations, cadres strongly associated with them, or former leaders who had made political careers within the PT. ${ }^{42}$

A survey reported by d'Araujo shows the extent to which leaders in civil society or PT members with a 'double militancy', both in the party and within CSOs, came to occupy strategic positions. In the Brazilian public administration the highest levels are the upper-level directions (or Direções de Asesoramento Superiores, DAS), level 5 and 6; and the special posts (or Cargos de Natureza Especial, NES). D'Araujo found that in 200645 per cent of all the DAS level 5 and 6 posts, and the NES roles belonged to a trade union; 10.6 per cent participated in a peak labour organisation and 46 per cent in a social movement. Among those who were also PT members, 45 per cent were part of a trade union; 36.7 per cent participated in a peak labour organisation and 56 per cent in a social movement. ${ }^{43}$

Leaders from many organisations in the PT field, many of whom had never occupied public office, were invited to participate in government on a sectorspecific basis in which the distribution of quotas among different groups became standard practice. Among others, leaders of the Housing Movement and intellectuals who identified with their demands became government officials in the first Lula administration. ${ }^{44}$ Associates of CONTAG occupied several positions in the Ministry of Rural Development, in which they negotiated the appointment of at least three important posts as Secretaries: Technical Assistance, Rural Credit and Territorial Reorganisation. ${ }^{45}$ The MST mainly negotiated positions at the Instituto Nacional de Colonização e Reforma Agrária (INCRA) and its offices in several states, in spite of the fact that most MST leaders deny an involvement in the administrative apparatus. ${ }^{46}$ One of these appointees, an interviewee for this study, was Clarice dos

${ }^{4}$ Maria Celina d'Araujo, Governo Lula: contornos sociais e politicos da elite do poder (Rio de Janeiro: CPDOC, 2007), p. I 5 .

42 A large number of Lula's appointees were neither from allied social movements, nor from the PT. Rather, they were nominated by allied parties in the congressional coalition, in particular the Partido do Movimento Democrático Brasileiro (PMDB) and the Partido Progressista (PP), the largest PT allies.

43 D'Araujo, Governo Lula: contornos sociais e politicos da elite do poder, pp. 44-5.

44 This was reported by Evaniza Rodrigues, interview on I 2 Dec 2008, a member of the executive committee of the National Union of Popular Housing (UNMP) who became Under Secretary of Urban Policy.

45 Branford, 'Lidando com governos'.

${ }^{46}$ MST leaders offer different versions about their involvement in government. In general, its main leaders tend to deny that they negotiated positions in the Lula administration. João Pedro Stédile said: 'The MST and the social movements have no participation in the government whatsoever. On the contrary, we behave with total autonomy' (João Pedro Stédile, interview, 6 Nov. 2007). In contrast, when I asked Clarice dos Santos whether the 
Santos, who developed her political career simultaneously in the MST and the PT in the state of Rio Grande do Sul. In 2005 she received support from the MST to become Director of the National Programme of Education and Land Reform (PRONERA) at INCRA.

More than any other organisation, CUT-affiliated trade union leaders or former leaders were rewarded with jobs throughout the administrative apparatus. In his first administration, Lula appointed $\mathrm{I} 2$ union leaders as ministers about one third of the cabinet positions, most of whom also had long trajectories as PT members. ${ }^{47}$ Between 2003 and 2007 the Ministry of Labour was consecutively occupied by three members of CUT: in 2003, by Jacques Wagner, from the oil sector trade union; between 2004 and 2005 by Ricardo Berzoini, a leader of the bank sector trade union, who had remained active in this organisation until the late I990s, and finally, by Luiz Marinho.

In spite of the fact that several CUT leaders had already held public office (both Berzoini and Wagner were congressional representatives several times), others had no previous experience in public office, whether in state institutions or in the PT bureaucracy. For instance, when Marinho was elected as CUT president in June 2003 , he had not occupied either an executive or a legislative position, or any relevant position within the PT apparatus. In 2005 he became Minister for Labour and two years later was appointed Minister for Social Security. Union leaders or former union members occupied between 50 and 60 senior positions at the level of Secretaries and thousands of second- and third-level jobs. ${ }^{48}$ Undoubtedly, many of these cadres had already occupied positions in the PT structure and wore 'double hats' as both party and social activists. However, an unquantified number only came to occupy positions in public office after Lula came to power.

It is undeniable that the incorporation of leaders from a 'popular' background who had not had meaningful access to the administration in the past had great importance in terms of both social inclusion and representation. The number of trade union leaders who participated in the Lula administration is impressive if one considers that trade union membership rate in Brazil is only i 4.5 per cent and during the Lula administration only 5 per cent of the high ranking officials were part of a business organisation. ${ }^{49}$ Many leaders interviewed for this study regarded the inclusion of social

appointment of many cadres to INCRA 'who sympathise with the MST' was part of negotiation with the government, she gave a straight forward answer: 'Yes, I was never involved in those talks, but I know they took place. All social movements made these sorts of negotiations' (Clarice dos Santos, interview, 7 April 2009).

47 Souza, 'Os ministros da Nova República', pp. 43-4.

${ }^{8}$ Jornal do Brasil is Aug. 2003, quoted in Hochstetler, 'Civil Society in Lula's Brazil', p. I I.

49 Souza, 'Os ministros da Nova República'; Maria Celina d'Araujo, A elite dirigente do governo Lula (Rio de Janeiro: Fundação Getulio Vargas, 2009). 
activists and trade union leaders in government as a natural phenomenon. ${ }^{\circ}$ João Felício, for instance, argued that during the Cardoso administration parties such as the Brazilian Social Democratic Party (PSDB) or the Democrats (DEM) appointed businessmen to public office. ${ }^{51}$ In his view, 'there is nothing wrong in the PT appointing members of its own social base'.

Yet the recruitment strategy deployed by the Lula administration also had consequences for civil society organisations in the PT entourage, which eventually helped to secure social governability. The peak labour organisation, in particular, had difficulties in maintaining its independence to criticise and put pressure on the government, particularly during Lula's first years in office, as many of its members acknowledged. ${ }^{52}$ Members of the CUT's secretariat wondered whether this situation created 'an identity crisis' in which 'even those cadres who were not properly in the administration considered themselves as being the government'. ${ }^{53}$ 'People were very confused about what was the government, what was the party and what was the union', CUT's President, Arthur Henrique, recalls. ${ }^{54}$ Nonetheless, other union and social movement leaders argued that, although having some of their members in government created constraints, it also gave them the capacity to make direct demands on their colleagues who were occupying administrative jobs and to make them more accountable.

Having their cadres in government had a mixed effect for the PT's social allies, notwithstanding the fact that, within the party field, many union and social movement leaders (particularly in the case of the CUT) were party cadres as well. A question arises about the extent to which this situation helped to promote programmatic linkages between the PT and its social allies. There is no simple answer. In some situations, CSOs were successful in using government spaces to promote their own agendas. Union leaders who became ministers for labour, for instance, were able to promote minimum wage increases that benefited various categories of workers. Likewise, housing activists in the Ministry of Cities articulated several demands that had been on their agendas for a number of years. The creation in 2003 of a ministry capable of articulating housing issues was in itself one of these demands. 55

50 Interviews with Ester Bemerguy, 20 July 2009, Secretary to the Economic and Social Development Council; João Felício, 28 Oct. 2008, president of CUT; and Guillermo Lacerda, 22 Jul 2009, president of FUNCEF.

${ }^{51}$ Interview with João Felício, 28 Oct. 2008.

52 Interviews with José Celestino, CUT's secretary for training, I 6 Dec. 2009; Artur Henrique, I 5 Apr. 2009 and Claudir Nespolo, member of CUT's executive commission in Rio Grande do Sul, 16 Dec. 2008.

53 Interview with José Celestino, I 6 Dec. 2009, author's emphasis.

${ }^{54}$ Interview with Artur Henrique, I5 April 2009.

55 Interview with Evaniza Rodrigues, 12 Dec. 2009. 
In other cases, however, former union and social movement leaders promoted policies or reforms that were opposed by the organisations in which they used to participate or by certain groups within these organisations. The case of the CUT offers two examples. Luiz Marinho, as Minister for Labour, promoted legislation that limited the right to strike among public sector workers, something the peak labour organisation opposed. Likewise, Ricardo Berzoini, as Minister for Social Security, promoted the reform of the pension fund system and a bill to reform the social security pension system, which affected the interests of the public sector trade unions, most of them affiliated to the CUT, and the largest component within this organisation. ${ }^{56}$ During the previous administration, both the CUT and the PT had opposed this bill, given that it equated the rights of public sector unions to those of the private sector. ${ }^{57}$ Forming part of the second generation of reforms prescribed by the World Bank and promoted by financial institutions worldwide, this bill was in great part an attempt to accommodate the interests of the financial establishment, a key element of Lula's economic policy strategy..$^{8}$

Nevertheless, the relationship between the PT government and the CUT deserves further comment, as it was greatly influenced by Lula's personality. In June 2003, for instance, the president attended the CUT's Eighth National Congress and used his authority and persuasive power as a leader and as head of state to support his governability strategy among CUT unionists. The labour congress took place at a time when the Lula administration had put in place a macroeconomic policy that frustrated the aspirations of progressive social organisations. It also happened shortly after the government had introduced the bill to reform the social security pension system.

At this critical moment, Lula addressed the CUT audience and emphasised his strong identification with the Central. He presented himself as the CUT's founding father and spoke to its members in a paternal fashion, as someone who knows what is best for the audience and best for the country. Between

${ }^{56}$ In 2003, when the CUT's Eighth National Congress took place, 40 per cent of its delegates represented unions in the public sector. In contrast, the industrial sector only represented I 6 per cent of the organisation ('CUT "envelhece" e se aproxima do Estado', Folha de São Paulo, 2 May 2004).

57 The reform of the social security pension system also allowed the creation of private funds and deprived public sector workers of previously gained benefits, such as fiscal exceptions among state workers' pensions or the so-called aposentadoria integral (the right to obtain a pension based on the highest salary earned and the number of years worked, rather than on a fixed retirement age). This reform was meant to tackle the fiscal deficit and change a system that was considered extremely costly.

${ }^{8}$ Merilyn Escobar, "Sob o signo do "novo sindicalismo": das mudanças de identidade e de estratégia, na trajetória do PT e da CUT, à consolidação do populismo sindical no governo Lula', unpublished Master's thesis, Ciências Sociais, Pontifícia Universidade Católica de São Paulo, 2008; Andréia Galvão, 'Syndicalisme et politique: la reconfiguration $\mathrm{du}$ mouvement syndical brésilien sous le gouvernement Lula', paper given at Congrès International Marx V, Paris-Sorbonne et Nanterre, 2007. 
jokes, the president told members that they were all members of a common family and he explained the need for certain policies and reforms. 59 Nevertheless, Lula also made promises. He told them: 'this companheiro metalúrgico from the North-east and from Pernambuco, who arrived at the Presidency of the Republic because of you and your responsibility, will not forget his historical commitments'. ${ }^{60}$ He received a standing ovation. Yet the president also was also booed a group of radical union leaders who opposed the controversial aspects of the government policies. Lula, the master of improvisation, told the dissidents: 'You know that I do not mind boos. To me boos are as important as applause. Some people used to boo me because I intended to create the PT. Some people even booed me because I wanted to create CUT', ${ }^{61}$

The CUT's dominant faction and a number of union leaders were particularly influenced by Lula's leadership, which became an important factor in securing social governability. For them, the election of a former metalworker had a 'strong symbolic character' and it was seen as the 'culmination of a historical process', as the CUT's president from 2006 emphasises. ${ }^{62}$ This symbolic character was so important that among certain union leaders, particularly in the private sector, the president benefited from unquestioned support. One of these leaders was the CUT's vice-president, José Lópes Feijóo, who belonged to the ABC Metalworker's Trade Union, the same one in which Lula initiated his career as a union leader. Lópes Feijóo, who never occupied any party position (he only joined the PT in 2005) or held public office, went as far as saying: 'Even if the government had performed very poorly, it still would have been [an] incredibly important [government] because we were able to elect a president as a result of 30 years of struggle' ${ }^{63}$ His words show the tremendous importance which Lula's leadership had in securing social governability. The president could sometimes count on something close to a blank cheque for support among certain union leaders.

Lula's informal leadership, coupled with the strong influence the PT always had over the CUT, particularly over its dominant faction, was used to orchestrate the succession to the Central's presidency during its Eighth Congress in 2003. Since 1999 João Felício, head of the schoolteachers' union, had led the peak labour organisation, whose leadership was strongly associated with the public sector workers, more combative than those unions associated with the private sector at the time. The party in government and its supporters

59 'Every time I participate in a CUT Congress', he began by saying, 'I feel as if I was at home talking to my wife and my sons, I feel as if I was in my house among companheiros' ('Lula e a CUT', Folha de São Paulo, I 7 June 2003).

${ }^{60}$ Ibid.

${ }^{61}$ Ibid.

${ }_{62}$ Interview with Artur Henrique, I5 April 2009.

${ }^{63}$ Interview with José Lopes Feijóo, 16 Dec. 2009, vice-president of the CUT. 
opposed his re-election as CUT president, most likely because his union base was reluctant to support the reform of the pension fund system, which affected schoolteachers deeply. The CUT had a tradition of re-electing its presidents, but this time they opted for a candidate supported by Lula, Luiz Marinho. Marinho was handpicked by President Lula and benefited from his endorsement. Given the inclination of Lula and his government to engage in negotiations with civil society organisations, CUT members who supported Marinho argued that his experience as a skilful negotiator made him the most suitable candidate for the job. ${ }^{64}$ Those who supported Felício, in contrast, claim that the former schoolteacher intended to adopt a more critical and independent position towards the government. ${ }^{65}$

Under Marinho's leadership, the CUT intended to mediate between its grassroots and the government without taking sides. In the reform of the pension fund system, for instance, the organisation did not give full support to public sector unions, despite the importance of this category within the CUT. In principle, the Central did not oppose the reform as a whole, but tried to negotiate with the administration in order to soften some of its most sensitive aspects. ${ }^{66}$ Public sector unions, however, took a hard line by formally requesting the bill to be withdrawn from Congress and eventually by voting for a general strike. ${ }^{67}$ The CUT leadership was initially reluctant to support this and refused to sign a petition requesting the bill's withdrawal. ${ }^{68}$ Eventually, however, the Central had no option but to support the strike, although it never organised any strong resistance against the government's proposal. ${ }^{69}$ The reform was passed in Congress without major changes.

\section{State Subsidies}

The Lula administration allocated massive state subsidies to CSOs..$^{\circ}$ This willingness to distribute an unprecedented amount of resources helped to secure ${ }^{64}$ Ibid.

${ }^{65}$ Interview with José Celestino, 16 Dec. 2009.

66 'CUT abandona trégua e ameaça greve', Folha de São Paulo, 18 July 2003; Galvão, 'Syndicalisme et politique', pp. 3-4.

67 'Lula e a CUT', Folha de São Paulo, 27 June 2003.

${ }^{68}$ The reform of the pension funds system was not the only occasion in which the CUT failed to support strike actions of a particular trade union sector affiliated to it. In 2004 the organisation made 'all possible attempts' to avoid a strike decided by the public sector bank workers, most likely because it might affect the municipal elections that were to take place that same year (Garcia, 'Partido dos trabalhadores'). In 2006 something similar happened in the context of the 2006 presidential election (Galvão, 'Syndicalisme et politique', p. 4).

${ }^{69}$ Ibid, p. 4 .

70 The allocation of state resources to CSOs and its implications during the Lula administration are understudied. While students of the PT have paid little attention to this issue, case studies of specific organisations, most notably the MST, have also failed to address it: see, among others, George Meszaros, 'O MST e o estado de direito no Brasil', in Carter (ed.), 
social governability, by engaging these groups in intensive negotiations with the state or collaborative efforts with the government, rather than promoting disruptive forms of collective actions. CSOs in the PT field used these resources tactically, sometimes to benefit their constituencies and maintain the support of their grassroots, sometimes to solve practical needs and secure their own material survival. This had some negative consequences, however, because organisations in the PT social network concentrated most of their time in specific negotiations to obtain concrete benefits from their allies in public office that did not necessarily change the rules of the game but drove energies away from substantive policy discussions.

The allocation of state resources to CSOs, a hallmark of the Lula administration, included both the distribution of particularistic benefits to specific groups, and the distribution of resources to benefit their constituencies in more general ways. ${ }^{71}$ The government provided generous funding to CSOs from the start, probably more than any previous Brazilian administration. $7^{2}$ This was largely possible because of the economic bonanza that the country experienced between 2003 and 2010 , when GDP grew at over 4 per cent per annum, public expenditure increased from 15.7 to 18.0 per cent of the GDP and investment from 0.4 to 1.3 per cent. ${ }^{73}$ Reliable figures for CSO funding are not available, largely because state funding to social groups has historically lacked transparency in Brazil. ${ }^{74}$ According to press sources, however, in 2003 alone, CSOs received Reais \$I.3 billion (US\$ 433,333) from the federal government, although this figure was not disaggregated.75

The administration used very different strategies to allocate public resources among different types of social organisations, not only those in the PT sociopolitical field. It transferred large sums to rural cooperatives and NGOs associated with the MST to provide technical assistance, training courses or the like. An inquiry carried out by an NGO, Contas Abertas (Open Accounts), found that between 2003 and 2009 the government provided R\$ I 52 million to 43

Combatendo a desigualdade social, pp. 433-70; Leonardo Vergara-Camus, 'The Politics of the MST: Autonomous Rural Communities, the State, and Electoral Politics', Latin American Perspectives, 36: 4 (2009), pp. 178-91.

${ }^{71}$ It is not always easy to draw a line between general and particularistic benefits, in part because they sometimes overlap. While some state subsidies are the bases of reward-based linkages, others might have more programmatic features.

${ }^{72}$ Hochstetler, 'Civil Society in Lula's Brazil', p. 48; author's interview with Joaquin Soriano, member of the PT National Directorate, 4 Nov. 2008.

73 'Ritmo de aumento do gasto público no governo Dilma pode superar o de Lula', O Estado de S.Paulo, i 8 Dec. $20 \mathrm{II}$.

74 Interviews with Selvino Heck, I April 2009, presidential advisor; José Antônio Moroni, 7 July 2009, coordinator the Brazilian Association of NGOs; and Joaquin Soriano, 4 Nov. 2008, PT secretary for training.

75 O Globo, 3 May 2004, cited in Hochstetler, 'Civil Society in Lula's Brazil', p. 48. 
rural cooperatives linked to the MST. ${ }^{76}$ According to the mass media, usually biased against the movement, the main leaders of these organisations were associated with the Landless Movement, although its leaders have persistently denied it. ${ }^{77}$

In fairness, the Lula administration did not initiate these policies. It is widely recognised that funding CSOs became a common practice under the neoliberal approach adopted during the I990s, both in Brazil and Latin America. ${ }^{7}$ As the state was withdrawing from many of its direct responsibilities, governments transferred vast amounts of resources to social organisations through which they delivered public services. During the I990s, in particular, several groups in the PT field such as CUT and the MST turned into major recipients of state subsidies. ${ }^{79}$ Some eventually became highly dependent on them. ${ }^{8 \circ}$ Yet the Lula administration funded civil society organisations even more generously.

${ }^{76}$ Folha de São Paulo, 'Repasse federal ao MST cai 25\% por ano desde 2004', 27 Feb. 2009; Folha de São Paulo, 'MST multiplica entidades para não perder repasses federais, 29 March 2009.

77 'Por dentro do cofre do MST', Veja, no. 2 1 28, 2 Sep. 2006; Folha de S. Paulo, 27 Feb. 2009, 29 March 2009. According to an MST leader, the movement does not receive state subsidies; only 'entities or technicians' linked to them receive 'money from the government' (interview with Evelaine Martines, 7 July 2009).

${ }^{78}$ Evelina Dagnino, 'Meanings of Citizenship in Latin America', Brighton, Institute of Development Studies, Working Paper 258, 2005.

79 See Carneiro, 'Uma concessão ao passado'; Felipe Demier, As transformaçóes do PT e os rumos da esquerda no Brasil (Rio de Janeiro: Bom Texto, 2003); Andréia Galvão, 'La CUT en la encruzijada: impactos del neoliberalismo sobre el movimiento sindical combativo', Revista Venezolana de Economía y Ciencias Sociales, Io: I (2004), pp. 219-39; Kathryn Hochstetler, 'Democratizing Pressures from Below? Social Movements in New Brazilian Democracy', paper presented at the Latin American Studies Association XX International Congress, Guadalajara, Mexico, I7-19 April, I997; Z Zander Navarro, "Mobilization without Emancipation": The Social Struggles of the Landless in Brazil', in Boaventura de Sousa Santos (ed.), Another Production Is Possible: Beyond the Capitalist Canon (London: Verso, 2006), pp. I $46-78$.

80 The MST engaged in the delivery of public services such as technical assistance, production and education in its settlements in spite of its anti-state discourse, its proclamations of autonomy and the fact that it maintained land occupations and other forms of disruptive action. As Navarro explains, MST leaders became 'mediators of government policies', such as the National Programme for the Invigoration of Family Agriculture (PRONAF), in great part aimed at the MST settlements (Zander Navarro, 'Mobilization without Emancipation', p. 16I). Yet the movement did not receive state resources directly. It deployed a wide range of rural cooperatives whose leaders were closely linked to the organisation (ibid., p. 165). The CUT managed the resources of the Workers' Assistance Fund (Fundo de Amparo ao Trabalhador, FAT), a mechanism initially created by the 1988 constitution as an unemployment security scheme. With these resources, the organisation promoted the creation of job agencies and put in place programmes of professional requalification and productivity promotion, among other initiatives (see Galvão, 'La CUT en la encruzijada', p. 232). The resources of FAT grew significantly during the i990s. By 2003, around 70 per cent of the funding received by CUT depended on this single mechanism (Demier, $A s$ transformaçóes do PT, p. 17). 
An indirect type of subsidy derived from the expansion of rural credit for small-scale farmers managed by the Ministry of Rural Development benefited the members of many rural organisations such as CONTAG, the Movement of Small Farmers (MPA) or the MST. The National Programme for the Invigoration of Family Agriculture (PRONAF) alone expanded from $\mathrm{R} \$ 2.4$ billion in $200 \mathrm{I}-02$ to $\mathrm{R} \$ \mathrm{I}_{3}$ billion in $2008 .^{8 \mathrm{I}}$ Although the resources allocated to this programme were not nearly as high as those channelled into the agribusiness sector, its expansion was important in promoting small-scale agriculture and alleviating poverty in rural areas. ${ }^{82}$ Yet these resources also created a reward-based linkage. Although the resources of PRONAF were directly channelled to its beneficiaries, it is known, for instance, that the MST charges its members a portion (usually $3^{-5}$ per cent) of the credit they receive from the government. ${ }^{83}$ For these types of reasons observers argue that PRONAF became an important source of funding for organisations such as the MST. ${ }^{84}$

There is no substantive evidence that social organisations ceased to mobilise because they received state resources. By and large, CSOs experienced different phases in their positions with regard to the Lula administration. Some even scaled up certain forms of protest, calculating that there was a government willing to negotiate with them and an opportunity to advance their goals.

During the Lula administration, for instance, the average of land occupations was I.2 per day, above the 0.7 occupations per day that had occurred during the two Cardoso administrations. According to the Ministry of Rural Development, the total number of land occupations conducted by all rural organisations in the country was relatively low during the final two years of the Cardoso administration: 158 in $200 \mathrm{I}$ and 103 in the electoral year of 2002. In 2003 and 2004, however, they escalated to 222 and 327 respectively. It is considered that the MST was responsible for more than 50 per cent of all these occupations. ${ }^{85}$ Among the unions, particularly after 2007, when the economy started to grow, the number of strikes, which had reached very low levels in the late I990s (only 50 strikes took place in 1998 and 46 in

${ }^{81}$ Sue Branford, 'Lidando com governos', p. 424.

${ }^{82}$ Commercial agriculture benefited from debt renegotiations and abundant financing at generous terms, increasing its credit from R $\$ 18$ billion in 2002 (US\$7.5 billion) to R $\$ 65$ billion in 2009 (US\$38.2 billion): see Marcelo Fernandes Guimarães, 'Políticas Públicas para a Agropecuária', 47 Congresso Sober, Porto Alegre, 2009, p. 17.

${ }^{83}$ Marta Harnecker, Landless People: Building a Social Movement (São Paulo: Expressão Popular, 2003).

${ }^{84}$ Charles Mueller and Bernardo Mueller, 'The Evolution of Agriculture and Land Reform in Brazil, 1960-2006', Conference in Honour of Werner Baer, University of Illinois, I-2 Dec. 2006 , p. 29.

${ }^{85}$ Ministério de Desenvolvimento Agrario, 'Relatório de Ouviduria Agraria', 2008, p. 2. 
I999), peaked at 316 in 2007 and 4 II in $2008 .{ }^{86}$ Certain categories in the CUT such as the bank sector workers, the electricity sector and, in general, public sector unions, conducted strikes every year. ${ }^{87}$

In spite of all this, by allocating unprecedented state resources, the government encouraged more moderate mobilisation strategies and modified the way in which many organisations related to the executive branch. CONTAG, for instance, maintained its two most important national campaigns, the annual Grito da Terra (Cry of the Land), in which a thousand smallholders demonstrated against the government, and the Marcha das Margaridas, which gathered women farmers from all over the country. Nonetheless, these forms of collective action lost their strong anti-government rhetoric and became occasions on which leaders of the main rural federations in CONTAG negotiated resources with politicians in different ministries. ${ }^{88}$ Important demands were fulfilled in these negotiations, such as credit for small farmers, which expanded even beyond the original expectations. ${ }^{89}$

The MST also experienced the effects of state subsidies, despite the fact that the organisation continued promoting land occupations. This article cannot capture in detail the complexities of the relationship between the MST and the Lula government. Suffice it to mention that during most of the first year the movement generally supported the government, but gradually became less enthusiastic, presumably due to the lack of progress in land reform and the administration's conservative economic policy. ${ }^{\circ}$ By the time Lula started his second term, the leadership of the MST had adopted a more incendiary rhetoric to the extent of arguing that land reform could only take place 'under Socialism' 9' $^{\text {I }}$ Despite this, the allocation of massive state resources shaped the relationship with the government and kept confrontations at a manageable level. To a great extent, this was also because the organisation became more dependent than ever before on state resources for its own survival. Paul Singer, who was Secretary of Fair Trade during the Lula administration, put it bluntly: 'The MST cannot break [its relationships] with the administration because 500,000 people depend on credit from the Ministry of Rural Development'. $9^{2}$

The criticisms of the MST towards the Lula administration were always carefully weighted. The Landless Movement behaved pragmatically, as a party member in Porto Alegre said, 'knowing to what extent they could

${ }^{86}$ Marieke Riethof, 'Changing Strategies of the Brazilian Labor Movement: From Opposition to Participation', Latin American Perspectives, 3 I: 139 (2004), p. 39.

${ }^{87}$ Interview with Artur Henrique, is April 2009.

${ }_{88}$ Interview with David Schmidt, 3 Dec. 2009, advisor to the presidency.

${ }^{89}$ Interview with Manoel dos Santos, 3 July 2009, former President of CONTAG.

90 Kathryn Hochstetler, 'Civil Society in Lula's Brazil; Sue Branford, 'Lidando com governos'.

${ }^{91}$ Interview with Evelaine Martines, 7 July 2009, leader of the MST.

92 Interview with Paul Singer, 16 April 2009, Secretary for Fair Trade. 
criticise'. ${ }^{93}$ When discussing the effects of public funding on the organisation, Clarice dos Santos, director of the National Programme for Education and Land Reform (a programme which expanded its budget from $\mathrm{R}_{\text {\& } 3}$ to $\mathrm{R} \$ 70$ billion during the Lula administration), argued that the MST hardly ever criticised Lula. ${ }^{4}$ It condemned certain figures in government or it spoke against certain policies, but not against the administration as a whole, even less against the president. In 2005, for instance, when it was clear that land reform was not making progress, the MST leadership organised a large protest to show strength and put pressure on the government. During these events, the intellectual guide and most visible figure of the MST, João Pedro Stédile, made it clear that 'the march [was] not against the Brazilian government, but for agrarian reform and change in economic policy'. 95

Clarice Dos Santos acknowledged that in a context in which land reform was not making much progress, the resources that the MST obtained during the Lula administration were used pragmatically to keep the organisation alive and helped to deliver what she defined as 'concrete benefits to its followers'. In her view, credit, technical assistance and other policies that benefited the settlements were not only 'necessary', but they also 'help[ed] to acknowledge the role played by the MST and maintain its social base' ${ }^{96}$ Santos pondered during our interview that the MST 'could not survive just by having a radical strategy'. Some leaders of the MST, such as Gilmar Mauro, argue that state subsidies had a domesticating effect. 'The head thinks where the feet stand', he emphasised. ${ }^{77}$ Dos Santos also acknowledged that 'the amount of public resources [that the movement received] did diminish anti-government reactions'. However, she also argued that these resources benefited small farmers. In her view, 'this is a contradiction, with positive and negative effects'. ${ }^{9}$ Other leaders in both the movement and the PT also consider the allocation of state resources to be a 'natural' phenomenon, even a measure of redistributive justice, in a country where lobby groups from the business sector have received high subsidies and fiscal exemptions for many years. ${ }^{99}$

The policies of the Lula administration made CSOs in the PT field even more dependent on state resources than during the I990s, when these types of practices were initiated. This led to a tendency in which such organisations

93 Interview with Nilton Fisher, I 5 Dec. 2008, former Secretary for Education in Porto Alegre.

${ }^{94}$ Interview with Clarice dos Santos, 7 May 2009. On the budget figures, see Branford, 'Lidando com governos', p. 424.

95 Baiocchi and Checa, 'The Brazilian Workers' Party', p. 422.

${ }_{96}^{6}$ Interview with Clarice dos Santos, 7 May 2009.

97 Interview with Gilmar Mauro, 7 July 2009, member of the National Coordination of the MST.

${ }_{98}^{8}$ Interview with Manoel dos Santos, 7 May 2009.

99 Interview with Fernando Ferro, PT National Congressman, 2 July 2009; Jõao Pedro Stédile, interviewed in 'MST vai às ruas para garantir novos indices', Jornal do Brasil, 20 Oct. 2009. 
gravitated towards the state more in order to obtain benefits and satisfy practical interests. According to some interpretations, the massive state resources that these organisations received under Lula took them further away from both their own grassroots and society in general. A city councillor in the north-eastern state of Paraíba complained, for example, that 'social movements today spend most of their energies in the relationship with the government and very little in society. They no longer form popular assemblies or promote any initiative that invites civil society to participate in larger public discussions'. ${ }^{100}$

The relationship between the party in government and its allies in civil society thus became more instrumental from both sides and less programmatic in content. Rather than discussing policies, programmes or projects, it was mostly about bargaining for resources. Manoel dos Santos, president of CONTAG, complained, for instance, that rural organisations never came to discuss a 'development project for the rural world' capable of 'articulating consistent actions to promote land reform and develop the existing land settlements'. In his opinion, the Lula administration was only different from previous governments in this regard because it allocated a large amount of resources in the rural areas. However, 'the main problem for small scale agriculture is in the planning, management and execution of policies'. CONTAG's president regrets: 'Sadly, we never discussed [with this government] the agricultural model that we wanted to implement'. ${ }^{\text {Ior }}$

\section{Final Remarks}

This article has shown how the types of linkages that the PT in government established with civil society organisations acted as instruments to secure social governability. In particular, it has looked at two elements: the distribution of jobs in the state apparatus and the allocation of massive state subsidies. These practices were not introduced by the Lula administration: they started when the PT governed at the sub-national level and during the I990s, when civil society organisations became large recipients of public resources. Yet the Lula administration took such practices even further. Lula probably appointed more trade unionists and social movement leaders to official posts than any previous Brazilian president, including President Getulio Vargas and President João Goulart, and his government provided more funding to civil society organisations than any previous Brazilian administration.

This article has shown how the distribution of public resources played an important role in accommodating the interests of social groups under Lula. It should be said, however, that a wide range of groups and actors - not

${ }_{100}^{100}$ Interview with Jorge Camilo, 16 Nov. 2010.

${ }^{101}$ Interview with Manoel dos Santos, 3 July 2009. 
only PT allies - benefited from such resources during these years. These resources were available not only because the Brazilian state imposes a heavy tax burden by Latin American standards, but also because of the international and national economic context. Indeed, the economic bonanza allowed the PT government a margin for manoeuvre to accommodate the interests of a wide range of groups simultaneously, as part of a general strategy to secure governability in its economic, social and political dimensions. ${ }^{102}$

Beyond reward-based linkages, however, there are other factors that contributed to social governability which have not been analysed in depth here. One was the willingness of the party in public office to deliver on many of its campaign pledges and fulfil some of the demands of its allies in civil society. Another is the strong leadership exercised by Lula over the PT field. Yet another is the existence of strong interpersonal linkages between party leaders and social activists with a common history, shared values and interests. The combination of all these features managed to produce a certain arrangement that allowed the PT in public office to maintain the political support of its social base, generated a reasonable level of social stability, maintained disruptive collective actions at manageable levels and decreased the level of criticism against the administration.

This article has permitted a more nuanced understanding of the complexities of the relationships between progressive parties in public office and their social allies. During the Lula years, many of these allies did a trade-off which had both positive and negative consequences. Working in government helped some leaders to promote their agendas, but it generated constraints and often made them lose capacity to make criticisms. Receiving massive resources helped to improve the lives of small farmers and the practical needs of their organisations, but made them gravitate almost entirely around the state (and be less concerned in modifying rules and the status quo). Exploiting personal connections sometimes helped to redistribute public goods and shape certain policies, but promoted relationships that mainly rendered particularistic benefits.

Scholars have argued that, by depending on the state for jobs or subsidies, social organisations become organisationally weak and narrow their activities to very specific concerns, while in their discretionary logic they promote a detachment from broader programmatic interests. ${ }^{103}$ It was not the intention of this article to determine if this is what occurred with civil society

102 This argument is developed further in Gómez, Lula, the PT and the Governability Dilemma in Brazil.

${ }^{103}$ Kevin Middlebrook, The Paradox of Revolution: Labor, the State, and Authoritarianism in Mexico (Baltimore, MD: Johns Hopkins University Press, I 995); Kenneth Roberts, 'PartySociety Linkages and Democratic Representation in Latin America', Canadian Journal of Latin American and Caribbean Studies, 27: 53 (2002), pp. 9-34. 
organisations during the Lula years. As far as the PT is concerned, the increasing predominance of reward-based linkages is regrettable because it was often at the expense of programmatic linkages. ${ }^{104}$ Such linkages are important to progressive politics, as Kenneth Roberts argues, because they help parties and civil society organisations to complement each other in positive ways, 'encourage collective rather than individualistic solutions', and 'politicize inequalities'. ${ }^{\text {I05 }}$ Reward-based linkages, in contrast, are considered as obstacles to progressive politics because their discretionary logic promotes a 'detachment from the broader programmatic interests of the poor', ${ }^{106}$ or even because they act as 'mechanisms of class control' that 'depoliticize social inequalities'. ${ }^{107}$ By dissolving some of its programmatic linkages and strengthening reward-based linkages with its social allies, the PT lost some of the elements that had made it a qualitatively different political party, which had challenged the predominant way by which the Brazilian state and parties in Latin America have historically related to civil society organisations and citizens at large.

\section{Spanish and Portuguese abstracts}

Spanish abstract. Este artículo da una nueva interpretación de los cambios ocurridos en las relaciones partido-sociedad civil cuando partidos progresistas que se originan en las masas ganan el poder estatal. Para ello analiza la experiencia del Partido de los Trabajadores de Brasil (PT) durante la administración de Lula. La necesidad de preservar lo que aquí se define como "gobernabilidad social" cambia la naturaleza de las relaciones entre el partido y los movimientos sociales cuando los partidos políticos se mueven de la oposición al gobierno. El artículo muestra cómo el PT ya ejerciendo el poder ejecutivo nacional logró asegurar, en buena medida, una gobernabilidad social a través de premiaciones, como la distribución de empleos en el aparato estatal y la asignación de subsidios estatales masivos.

Spanish keywords: partidos políticos, movimientos sociales, sociedad civil, relaciones estado-sociedad, Brasil, PT, Lula

Portuguese abstract. Observando a experiência brasileira do Partido dos Trabalhadores (PT) durante o governo Lula, este artigo oferece uma nova interpretação acerca das mudanças que ocorrem nas relações partido/sociedade civil quando partidos progressistas com origens populares assumem o poder do Estado. A necessidade de preservar o

${ }^{104}$ See the argument in Gómez, Lula, the PT and the Governability Dilemma in Brazil, Ch 9. ${ }^{105}$ Kenneth M. Roberts, Deepening Democracy? The Modern Left and Social Movements in Chile and Peru (Stanford, CA: Stanford University Press, 1998), p. I 8.

${ }^{106}$ Kenneth M. Roberts, Changing Course: Party Systems in Latin America's Neoliberal Era (Cambridge: Cambridge University Press, forthcoming).

${ }^{107}$ Herbert Kitschelt, Mansfeldova Zdenka and Radoslav Markowski, Post-Communist Party Systems: Competition, Representation, and Inter-Party Cooperation (Cambridge: Cambridge University Press, 1999), p. 49. 
que definimos aqui como "governabilidade social" modifica a natureza das relações partido/movimentos sociais quando partidos políticos passam de oposição a governo. O artigo evidencia como, no exercício do executivo, o PT em grande medida conseguiu assegurar sua governabilidade social através de relaçóes baseadas na recompensa, como a distribuição de empregos públicos e a alocação de enormes subsídios estatais.

Portuguese keywords: partidos políticos, movimentos sociais, sociedade civil, relações estado-sociedade, Brasil, PT 